\title{
The Impact of Oil Shocks on Exchange Rates: The Case of Selected OPEC Countries
}

\author{
Shahram Fattahi ${ }^{1}$, Zainab Moridi ${ }^{1} \&$ Rasoul Moridi ${ }^{1}$ \\ ${ }^{1}$ Faculty of Social Sciences, Department of Economics, Razi University \\ Correspondence: Shahram Fattahi, Faculty of Social Sciences, Department of Economics, Razi University.
}

Received: February 7, 2021

Accepted: March 4, 2021

Available online: March 12, 2021

doi:10.11114/afa.v7i2.5188

URL: https://doi.org/10.11114/afa.v7i2.5188

\begin{abstract}
OPEC countries are heavily dependent on oil dollar revenues through which impact on exchange rates. The purpose of this study is to investigate the effect of oil shocks on the real exchange rates for selected OPEC countries for the period 1980-2018. The oil shocks are first obtained using the vector auto-regression model and then their effects on the exchange rates are estimated using a panel quantile regression model. The results show that effect of oil shocks on exchange rates varies across quantiles. The oil specific-demand shock and global demand shock have a negative and significant effect on the real exchange rates while the oil supply shock has a positive and significant effect on the real exchange rates in OPEC countries. Furthermore, oil specific-demand shock has the most impact on the real exchange rates.
\end{abstract}

Keywords: Oil Shocks, Exchange Rates, OPEC, Panel Quantile Regression Model

\section{Introduction}

OPEC was established in 1960 by five countries namely Iran, Iraq, Kuwait, Saudi Arabia and Venezuela. These countries were later joined by Qatar, Indonesia, Libya, the United Arab Emirates, Algeria, Nigeria, Ecuador, Gabon, Angola, Equatorial Guinea and Congo. However, some countries including Ecuador, Indonesia, Gabon and Qatar have suspended or terminated their membership so that, currently, this organization has a total of 13 member countries.

Oil is a main resource for OPEC countries and oil price movements have a severe impact on exchange rates in these countries because the oil shocks can affect oil revenues and, as a result, the exchange rates. The relationship between oil prices and macroeconomic variables was first proposed by Hamilton (1983).

Oil price fluctuations are one of the main sources of economic fluctuations in oil exporting countries. The importance of oil in the economy of OPEC member countries is such that its price change affects the prices of a large number of goods, services and economic activities. The OPEC oil exporters hold about two-thirds of the world's oil reserves. These countries generally have an oil-dependent structure, with a large share of their revenues coming from oil revenues. Oil shocks affect the monetary base of these countries, thereby destabilizing the real exchange rate. Given that oil revenues make up a large portion of OPEC member countries' export revenues and annual budget revenues, any increase or decrease in oil price directly or indirectly affects the economy and one of the most important economic indicators, namely the exchange rate. The real exchange rate is the transmission of oil price shocks from world markets to the economies of oil-exporting countries. On the other hand, many investment and foreign trade decisions depend on the exchange rate. Knowledge of how oil price fluctuations affect the exchange rate can be a good guide in planning and policy-making of government officials and economic planners (Reza-zadeh, 2016).

The real exchange rate is considered as an indicator of the competitiveness of an economy in the international level. The exchange rate, on the one hand, has an effective role in exports and imports and subsequently regulates the trade balance and balance of payments of the country and, on the other hand, it plays an effective role in determining the competitiveness of domestic producers against foreign competitor and then determines the amount of production and employment. In oil-dependent countries, oil shocks are considered to be one of the most important factors affecting exchange rate fluctuations. In international oil markets, because the US dollar is used as a major currency in international payments, it is the channel through which oil price shocks are transmitted to the real sector of the economy and financial markets. Therefore, the impact of oil shocks on the exchange rate is of special importance. Several studies have evaluated the empirical relationship between oil prices and exchange rates. Huang and Guo (2007) found there is a 
weak evidence of a relationship between exchange rates and oil shocks, in which real oil price shocks lead to a slight increase in the exchange rate. On the other hand, Amano and Van Norden (1998) suggest that there is a strong correlation between oil prices and exchange rates.

Oil shocks affect the foreign exchange market through oil prices, obviously this effect can be in the form of increasing or decreasing the exchange rate. Theoretically, oil price shocks may affect the exchange rate in a country through two channels: the term of trade channel and the welfare effect. The term of trade channel affects the two groups of oil exporting and importing countries in different ways. In oil-importing countries, rising oil prices weaken the trade balance and, as a result, devaluating their national currencies. Conversely, in oil-exporting countries, a positive oil shock may lead to Dutch disease and an increase in the value of their national currencies by increasing the prices of non-tradable goods. Backus and Crucini (2000) showed that changes in oil price determinants lead to changes in term of trade. The distinction between oil-exporting and oil-importing countries becomes clearer when the welfare channel is also considered. Accordingly, an increase in oil prices is associated with the transfer of welfare from importing countries to oil-exporting countries, which leads to a decrease in the real value of the national currency in importing countries and an increase in the real value of the national currency in oil-exporting countries, which result in the current account imbalance.

\section{Literature Review}

The empirical literature on the relationship between oil prices and exchange rates suggests different directions. Recent studies on the relationship between oil prices and exchange rates have shown real oil prices may have been the dominant source of real exchange rate movements and that there is a link between real oil prices and real exchange rates. (Chen and Chen, 2007).

Zhang et al. (2008) examined the spillover effect of US dollar exchange rate on oil prices. They indicated that the influence of US dollar exchange rate on the international crude oil market proves quite significant in the long term; however, its short-term and instant influence turns out to be quite limited. Akram (2009) found the possibility of a nonlinear relationship between oil prices and the Norwegian exchange rate. He showed a negative relationship between oil prices and the value of the Norwegian exchange rate that is relatively strong when oil prices are below 14 dollars and are falling. Lizardo and Mollick (2010) concluded that the oil prices significantly explain movements in the value of the U.S. dollar (USD) against major currencies from the 1970s to 2008. Increases in real oil prices lead to a significant depreciation of the USD against net oil exporter currencies, such as Canada, Mexico, and Russia while the currencies of oil importers, such as Japan, depreciate relative to the USD when the real oil price goes up. Wang and Wu (2012) examined the relationship between energy prices and the dollar exchange rate using linear and nonlinear causality tests. They showed there are unidirectional linear causality running from petroleum prices to exchange rates and unidirectional nonlinear causality running from exchange rates to natural gas prices before the financial crisis 2008 while the bidirectional nonlinear causality relationships between petroleum prices and exchange rates can be found after the 2008 crisis.

Atems et al. (2015), applying Kilian's methodology, examined asymmetric exchange rate response to crude oil market shocks using monthly data for the period 1974-2013. They came to conclusion that oil supply shocks have no significant effects on exchange rates, while global aggregate demand and oil-specific demand shocks lead to depreciations. Furthermore, the exchange rates respond asymmetrically to shocks in the crude oil market depending on whether the shocks are large versus small, or positive versus negative. Basher et al. (2016) tested the effect of oil shocks on the real exchange rate for a sample of oil-exporting and importing countries. Their findings detected significant exchange rate appreciation pressures in oil exporting economies after oil demand shocks. There was limited evidence that oil supply shocks affect exchange while global economic demand shocks affect exchange rates in both oil exporting and importing countries. Law (2018) applied Breusch-Pagan heteroscedasticity test and showed using quantile regression to be an appropriate approach to understanding oil price and currency value. He concluded that the oil prices only depreciate the Thailand exchange rate in the cases of large appreciation, and this is explained the argument that the extreme large appreciation of exchange will be more sensitive to fundamental financial variables, including world oil prices.Liu et al. (2020) showed there is a significant negative relationship between oil shocks and exchange rates in the U.S. for the period 1996-2019. Shocks to crude oil prices have immediate and short-term impacts on movements in the exchange rate which are emphasized during the confidence intervals of structural breaks.

Although most studies have modeled oil shocks, and the impact of oil shocks on economic growth and exchange rate in different countries, little attention has been paid to examination of oil shocks impact on the real exchange rate in OPEC countries. 


\section{Method}

This study aims to examine the impact of oil shocks on exchange rates in OPEC countries using panel quantile model. First, the shocks are extracted based on the auto-regression vector (VAR) model. The structural VAR model is specified as follows:

$$
y_{t}=\alpha+\sum_{i=1}^{p} A_{i} y_{i . t}+e_{t}
$$

Where $y_{t}$ includes total world oil production, real world economic activity index and real oil prices. Also, in this model, the logarithmic difference of these variables is used. The $e_{t}$ represents the vector of structural disturbances. It is assumed that $e_{t} \quad$ is related to the fundamental crude oil markets shocks $\varepsilon_{t}$ according to $e_{t}=A_{0}^{-1} \varepsilon_{t}$. Thus, Eq. (1) can be rewritten as follows:

$$
A_{0} y_{t}=A_{O} \alpha+\sum_{i-1}^{P} A_{0} A_{i} y_{t-i}+\varepsilon_{t}
$$

There are three shocks: $\varepsilon_{1 t}, \varepsilon_{2 t}, \varepsilon_{3 t}$ which denote the oil supply shock, global aggregate demand shock, and the oil-specific demand shock, respectively. To identify $A_{0}^{-1}$, the following restrictions are imposed:

$$
e_{t}=\left(\begin{array}{c}
e_{1 t}^{\Delta p r o d} \\
e_{2 t}^{r e a} \\
e_{3 t}^{r p o}
\end{array}\right)=\left[\begin{array}{ccc}
a_{11} & 0 & 0 \\
a_{21} & a_{22} & 0 \\
a_{31} & a_{32} & a_{33}
\end{array}\right]\left(\begin{array}{l}
\varepsilon_{1 t}^{\text {oil supply shock }} \\
\varepsilon_{2 t}^{\text {aggregate demand shock }} \\
\varepsilon_{3 t}^{\text {oil demad shock }}
\end{array}\right)
$$

In the next step, the impacts of oil shocks on exchange rates are estimated using the following regression for the OPEC countries:

$$
E X R_{i . t}=B_{0, i}+B_{1 . i} \varepsilon_{t}^{s}+B_{2 . i} \varepsilon_{t}^{d}+B_{3 . i} \varepsilon_{t}^{p}+\varepsilon_{i . t}
$$

We apply quantile regression, instead of traditional linear regression, to estimate equation (4). In quantile regression, unlike linear regression, the minimization of the total absolute value of the residual residuals is used to estimate the model parameters, which is called the absolute minimum value of deviations or LAD (Koenker and Bassett, 1978). One advantage of quantile regression is that the quantile regression estimates are more robust against outliers. Moreover, we often prefer using different measures of central tendency and statistical dispersion to obtain a more comprehensive analysis of the relationship between variables. Quantile regression models the relationship between a specified conditional quantile of a dependent variable and one or more independent variables (Abbaspour et al, 2011).

\section{Results and Discussion}

The real exchange rate variable is calculated as the official exchange rate multiplied by the ratio of the general level of US prices to each OPEC member $(2011=100)$. The global oil production (in thousands of barrels) and oil price (in dollars per barrel) are obtained from the US EIA. To compute the real oil prices, oil prices are deflated by the CPI index. The global real economic activity index is available at Lutz Kilian's website. All data cover the period 1980-2018 and the selected OPEC countries include Algeria, Iran, Iraq, Kuwait, Libya, Nigeria, Qatar, Saudi Arabia, the United Arab Emirates and Venezuela.

Descriptive statistics of variables is shown in Table 1. The highest average of the real exchange rate variable belongs to Venezuela (210.72) while the lowest one belongs to Qatar (89.24). The highest standard deviation of the real exchange rate variable belongs to Venezuela while the lowest one belongs to Iraq. 
Table 1. Descriptive statistics of variables

\begin{tabular}{|c|c|c|c|c|c|c|}
\hline Country & Variable & Min & Max & Mean & Median & StDev \\
\hline \multirow{4}{*}{ Algeria } & Exchange rate & 97.98 & 240.99 & 182.33 & 120.85 & 112.87 \\
\hline & Oil supply shock & 19.25 & 458.62 & 30.09 & 2.60 & 8.92 \\
\hline & $\begin{array}{l}\text { Aggregate demand } \\
\text { shock }\end{array}$ & 27.11 & 48.30 & 33.32 & 3.00 & 5.04 \\
\hline & $\begin{array}{l}\text { Oil } \\
\text { specific-demand } \\
\text { shock }\end{array}$ & -26.62 & 6.021 & 6.81 & 8.24 & 3.00 \\
\hline \multirow{4}{*}{ Iran } & Exchange rate & 52.48 & 187.15 & 153.36 & 121.15 & 87.54 \\
\hline & Oil supply shock & 15.04 & 50.37 & 29.99 & 27.18 & 6.10 \\
\hline & $\begin{array}{l}\text { Agree gate demand } \\
\text { shock }\end{array}$ & 32.37 & 83.45 & 67.70 & 57.71 & 3.21 \\
\hline & $\begin{array}{l}\text { Oil } \\
\text { specific-demand } \\
\text { shock }\end{array}$ & 4.67 & 95.84 & 89.74 & 88.16 & 4.18 \\
\hline \multirow{4}{*}{ United Arab Emirates } & exchange rate & 79.77 & 112.54 & 94.66 & 95.71 & 70.3 \\
\hline & Oil supply shock & 23.55 & 39.39 & 33.08 & 32.59 & 4.28 \\
\hline & $\begin{array}{l}\text { Aggregate demand } \\
\text { shock }\end{array}$ & 18.53 & 28.05 & 111.04 & 23.65 & 2.42 \\
\hline & $\begin{array}{l}\text { Oil } \\
\text { specific-demand } \\
\text { shock }\end{array}$ & 5.94 & 12.30 & 14.50 & 3.63 & 5.87 \\
\hline \multirow{4}{*}{ Iraq } & exchange rate & 91.64 & 108.50 & 95.75 & 98.83 & 30.34 \\
\hline & Oil supply shock & 10.34 & 52.22 & 16.90 & 16.38 & 2.38 \\
\hline & $\begin{array}{l}\text { Aggregate demand } \\
\text { shock }\end{array}$ & 8.51 & 45.93 & 2.59 & 2.76 & 1.28 \\
\hline & $\begin{array}{l}\text { Oil } \\
\text { specific-demand } \\
\text { shock }\end{array}$ & 7.72 & 70.72 & 5.23 & 5.26 & 3.78 \\
\hline \multirow{4}{*}{ Saudi Arabia } & Exchange rate & 93.62 & 242.56 & 187.26 & 120.47 & 68.45 \\
\hline & Oil supply shock & 35.11 & 72.60 & 54.12 & 44.33 & 1.38 \\
\hline & $\begin{array}{l}\text { Aggregate demand } \\
\text { shock }\end{array}$ & 22.56 & 61.13 & 55.12 & 42.27 & 1.10 \\
\hline & $\begin{array}{l}\text { Oil } \\
\text { specific-demand } \\
\text { shock }\end{array}$ & 45.51 & 120.53 & 95.05 & 61.15 & 5.04 \\
\hline \multirow{4}{*}{ Kuwait } & Exchange rate & 86.26 & 214.30 & 198.86 & 167.78 & 60.50 \\
\hline & Oil supply shock & 9.65 & 24.24 & 17.94 & 18.13 & 0.30 \\
\hline & $\begin{array}{l}\text { Aggregate demand } \\
\text { shock }\end{array}$ & 14.25 & 25.02 & 17.93 & 17.54 & 0.24 \\
\hline & $\begin{array}{l}\text { Oil } \\
\text { specific-demand } \\
\text { shock }\end{array}$ & 5.56 & 55.40 & 41.44 & 48.38 & 1.068 \\
\hline \multirow{4}{*}{ Qatar } & Exchange rate & 70.32 & 102.76 & 89.24 & 92.46 & 11.31 \\
\hline & Oil supply shock & 0.78 & 2.50 & 1.95 & 2.00 & 0.40 \\
\hline & $\begin{array}{l}\text { Aggregate demand } \\
\text { shock }\end{array}$ & 1.66 & 2.15 & 2.04 & 2.04 & 0.09 \\
\hline & $\begin{array}{l}\text { Oil } \\
\text { specific-demand } \\
\text { shock }\end{array}$ & 5.18 & 59.98 & 19.91 & 26.66 & 2.43 \\
\hline Libya & Exchange rate & 86.71 & 180.59 & 116.98 & 101.98 & 27.12 \\
\hline
\end{tabular}




\begin{tabular}{|c|c|c|c|c|c|c|}
\hline & Oil supply shock & 11.57 & 16.63 & 16.01 & 16.02 & 0.01 \\
\hline & $\begin{array}{l}\text { Aggregate demand } \\
\text { shock }\end{array}$ & 14.39 & 25.59 & 16.95 & 14.57 & 1.41 \\
\hline & $\begin{array}{l}\text { Oil } \\
\text { specific-demand } \\
\text { shock }\end{array}$ & 10.09 & 12.10 & 18.90 & 17.37 & 0.23 \\
\hline \multirow{4}{*}{ Nigeria } & Exchange rate & 85.10 & 145.21 & 93.36 & 92.82 & 47.97 \\
\hline & Oil supply shock & 15.82 & 19.02 & 18.01 & 16.90 & 0.07 \\
\hline & $\begin{array}{l}\text { Aggregate demand } \\
\text { shock }\end{array}$ & 5.04 & 36.95 & 28.40 & 25.26 & 8.13 \\
\hline & $\begin{array}{l}\text { Oil } \\
\text { specific-demand } \\
\text { shock }\end{array}$ & 19.17 & 19.17 & 1.44 & 2.26 & 3.13 \\
\hline \multirow{4}{*}{ Venezuela } & Exchange rate & 76.08 & 382.76 & 210.72 & 91.19 & 98.74 \\
\hline & Oil supply shock & 8.58 & 93.47 & 82.04 & 88.55 & 2.37 \\
\hline & $\begin{array}{l}\text { Aggregate demand } \\
\text { shock }\end{array}$ & 14.54 & 89.35 & 77.03 & 76.00 & 1.41 \\
\hline & $\begin{array}{l}\text { Oil } \\
\text { specific-demand } \\
\text { shock }\end{array}$ & 2.26 & 39.84 & 28.34 & 32.79 & 3.92 \\
\hline
\end{tabular}

Source: Research Findings

The highest average of the total demand shock variable belongs to the United Arab Emirates while the lowest one belongs to Qatar. The highest standard deviation related to the total demand shock variable belongs to Nigeria while the lowest one belongs to Qatar. The highest average of the global oil demand shock variable belongs to Saudi Arabia while the lowest one belongs to Nigeria. The highest standard deviation related to the global oil demand shock variable belongs to the United Arab Emirates while the lowest one belongs to Libya.

Before estimating the research model, a statistical test is required for stationarity of the variables. The Levin, Lin and Chu (LLC), Im, Pesaran and Shin (IPS), Augmented Dickey-Fuller (ADF) and Phillips-Perron (PP) Fisher chi-Square tests are used to test whether a variable possess a unit root. Table 2 presents the results of the panel unit root test, indicating that all variables are stationary.

Table 2. Results of Panel Unit Root Tests

\begin{tabular}{l|l|l|l|l}
\hline \multirow{2}{*}{ Variable } & Panel Unit Root Test & Statistic & Prob. & $\begin{array}{l}\text { Order } \\
\text { Integration }\end{array}$ \\
\hline \multirow{5}{*}{ Exchange rate } & LLC & 2.04 & 0.02 & $\mathrm{I}(0)$ \\
\cline { 2 - 5 } & IPS & 3.02 & 0.00 & $\mathrm{I}(0)$ \\
\cline { 2 - 5 } & ADF & 45.13 & 0.00 & $\mathrm{I}(0)$ \\
\cline { 2 - 5 } & PP-Fisher chi-Square & 46.68 & 0.00 & $\mathrm{I}(0)$ \\
\hline \multirow{5}{*}{ Ail supply shock } & LLC & 2.28 & 0.01 & $\mathrm{I}(0)$ \\
\cline { 2 - 5 } & IPS & 2.13 & 0.01 & $\mathrm{I}(0)$ \\
\cline { 2 - 5 } & ADF & 47.69 & 0.00 & $\mathrm{I}(0)$ \\
\cline { 2 - 5 } & PP-Fisher chi-Square & 40.15 & 0.01 & $\mathrm{I}(0)$ \\
\hline \multirow{5}{*}{ Oil specific-demand shock } & LLC & 48.93 & 0.00 & $\mathrm{I}(0)$ \\
\cline { 2 - 5 } & IPS & 69.55 & 0.00 & $\mathrm{I}(0)$ \\
\cline { 2 - 5 } & ADF & 35.27 & 0.03 & $\mathrm{I}(0)$ \\
\cline { 2 - 5 } & PP-Fisher chi-Square & 39.66 & 0.01 & $\mathrm{I}(0)$ \\
\cline { 2 - 5 } & LLC & 1.71 & 0.04 & $\mathrm{I}(0)$ \\
\cline { 2 - 5 } & IPS & 2.81 & 0.00 & $\mathrm{I}(0)$ \\
\cline { 2 - 5 } & ADF & 63.90 & 0.00 & $\mathrm{I}(0)$ \\
\hline
\end{tabular}

Source: Research Findings

Table 3 reports the results of estimated panel quantile regression model for the quantiles 0.1 to 0.9 . The results of the study show that oil specific-demand shock play a major role in determining the real exchange rate in OPEC countries.

Due to economic dependence on oil revenues, lower oil prices cause many problems including budget deficits, inflation, 
and the currency depreciation in these countries. The results also show that impact of oil shocks on exchange rates varies across quantiles.

Table 3. The Results of Estimated Panel Quantile Regression Model

\begin{tabular}{|c|c|c|c|}
\hline Quantile & Explanatory Variables & Coefficient & Prob. \\
\hline \multirow{4}{*}{0.10} & Oil supply shock & $6.58 \mathrm{E}-05$ & 0.00 \\
\hline & Aggregate demand shock & -0.000194 & 0.00 \\
\hline & Oil specific-demand shock & -0.000529 & 0.00 \\
\hline & Intercept & 2.070044 & 0.00 \\
\hline \multirow{4}{*}{0.2} & Oil supply shock & $4.97 \mathrm{E}-05$ & 0.00 \\
\hline & Aggregate demand shock & $-4.20-\mathrm{E} 05$ & 0.00 \\
\hline & Oil specific-demand shock & -0.011932 & 0.00 \\
\hline & Intercept & 2.281017 & 0.00 \\
\hline \multirow{4}{*}{0.3} & Oil supply shock & $5.63 \mathrm{E}-05$ & 0.00 \\
\hline & Aggregate demand shock & -0.002450 & 0.00 \\
\hline & Oil specific-demand shock & -0.007966 & 0.00 \\
\hline & Intercept & 2.748197 & 0.00 \\
\hline \multirow{4}{*}{0.4} & Oil supply shock & $5.67 \mathrm{E}-05$ & 0.00 \\
\hline & Aggregate demand shock & -0.002791 & 0.00 \\
\hline & Oil specific-demand shock & -0.009340 & 0.00 \\
\hline & Intercept & 2.943033 & 0.00 \\
\hline \multirow{4}{*}{0.5} & Oil supply shock & $9.87 \mathrm{E}-05$ & 0.00 \\
\hline & Aggregate demand shock & -0.002067 & 0.00 \\
\hline & Oil specific-demand shock & 0.004044 & 0.00 \\
\hline & Intercept & 2.869616 & 0.00 \\
\hline \multirow{4}{*}{0.6} & Oil supply shock & 0.000103 & 0.00 \\
\hline & Aggregate demand shock & -0.002337 & 0.00 \\
\hline & Oil specific-demand shock & -0.003370 & 0.00 \\
\hline & Intercept & 2.983455 & 0.00 \\
\hline \multirow{4}{*}{0.7} & Oil supply shock & $3.38 \mathrm{E}-05$ & 0.00 \\
\hline & Aggregate demand shock & -0.003001 & 0.00 \\
\hline & Oil specific-demand shock & -0.006910 & 0.00 \\
\hline & Intercept & 3.34255 & 0.00 \\
\hline \multirow{4}{*}{0.8} & Oil supply shock & 3. 3E-05 & 0.00 \\
\hline & Aggregate demand shock & -0.003253 & 0.00 \\
\hline & Oil specific-demand shock & -0.006240 & 0.00 \\
\hline & Intercept & 3.469967 & 0.00 \\
\hline \multirow{4}{*}{0.9} & Oil supply shock & $30.8 \mathrm{E}-05$ & 0.00 \\
\hline & Aggregate demand shock & -0.004702 & 0.00 \\
\hline & Oil specific-demand shock & -0.10149 & 0.00 \\
\hline & Intercept & 3.780572 & 0.00 \\
\hline
\end{tabular}

Source: Research Findings

Oil specific-demand shock and global demand shock have a negative and significant effect on the real exchange rate while the global supply shock has a positive and significant effect on the real exchange rate in these countries. One exception is the effect of Oil specific-demand shock on real exchange rates at quantile 0.5 which is positive. The results also show that oil supply shocks are smaller than total demand and oil demand shocks. In other words, during the period 1980-2018, fluctuations in total world crude oil production were less than fluctuations in the real activities of the global 
economy and specific oil demand. So that the big positive supply shock in early 1994 and a large and significant negative supply shock happened in mid-2015. World oil production in January 1994 increased by more than 7,500,000 barrels per day on average compared to the previous month. The increase in global demand and consumption in 1994 was the main reason for the further growth of crude oil production and supply in the world. Of course, the further growth of world oil supply during the early 1990s is due to further declines in oil prices. It should be noted that the Iraq-Kuwait war in the early 1990s was one of the main reasons for the fluctuations in oil supply during these years. Therefore, the use of strategic reserves have helped control oil price fluctuations. In mid-2015, after a negative shock in total oil production, world oil production increased, and this decrease was due to low oil prices. Total demand shocks show that the real activities of the global economy until 2008 had small fluctuations compared to the following years, but a large negative shock was observed this year, which testifies to the great economic recession in the world. In other words, the great financial crisis of the United States and Europe this year created a significant negative shock to the real activities of the global economy. In the following years, the range of fluctuations of this variable increased and in other words, the global economy experienced several positive and negative shocks. Thus, the great crisis of 2008 initially led to an increase in oil prices, but then and in the last months of 2008 there was a negative oil price shock. During the period 2011 to 2014, oil prices were often high, but in the last months of 2014, oil prices dropped, and in 2015, oil prices rose again. For OPEC member countries, oil supply shocks have a significant positive impact on the real exchange rate, which may be due to the discovery of new oil reservoirs, access to new technologies to extract more oil, or reduced OPEC control over oil supply.

Oil specific-demand shocks and global demand shocks have a significant negative impact on the real exchange rate. Positive shocks to oil demand and positive shocks to global demand, stemming from the global economic boom, cause oil prices to rise, which in turn lower the exchange rate and increasing the value of local currencies in oil-exporting countries. In other words, in OPEC member countries, which mainly earn huge revenues from oil exports, these revenues may be due to a sudden rise in oil prices. For oil-exporting countries, a positive shock to oil demand generally leads to an improvement in the trade balance and consequently an appreciation of the national currency, while negative oil price shocks can lead to a decline in the trade balance and a devaluation of the domestic currency. This would lead to a decrease in foreign exchange reserves by the central bank and an increase in the impact of oil shocks on the real exchange rate in these countries. It makes exchange rate fluctuations in these countries. Therefore, on the one hand, fluctuations in the price of the OPEC oil basket cause fluctuations in the value of the dollar, and on the other hand, fluctuations in the value of the dollar cause fluctuations in the net assets of the central banks of these countries and thus affect the monetary base. As a result, the changes in the monetary base cause fluctuations in the exchange rates of these countries.

\section{Conclusions and Policy Recommendations}

One of the most important macroeconomic debates and challenges is the effect of oil shocks on the real exchange rate. This study examined the effect of oil shocks on the real exchange rates for selected OPEC countries for the period 1980-2018. The results indicated that impact of oil shocks on exchange rates is heterogeneous across quantiles. The oil specific-demand shock and global demand shock have a negative and significant effect on the real exchange rates while the oil supply shock has a positive and significant effect on the real exchange rates in OPEC countries. Furthermore, Oil specific-demand shock has the most impact on the real exchange rates.

According to the results obtained, the following economic policies are recommended to control exchange rate fluctuations. One way to control exchange rate fluctuations is to use the foreign exchange reserve fund in the times of a decrease or fluctuation in foreign exchange earnings. The historical experience of OPEC countries has shown that the existence of a foreign exchange reserve fund with an independent management structure is necessary to control oil price fluctuations. The OPEC countries should also diversify products and develop non-oil exports. Finally, another key way in reducing the economic impact of oil prices and generating economic growth is to reduce the budget's dependence on oil and its products, which seems to be a short-term policy for OPEC countries.

\section{References}

Abbaspour, S., Fattahi, S., \& Nazifi, M. (2011). The Effect of Openness on Inflation, Using Quantile Regression: A Case Study of Iran. Retrieved January 17, 2018 from https://papers.ssrn.com/sol3/papers.cfm?abstract_id=2124478

Akram, Q. F. (2009). Commodity prices, interest rates and the dollar. Energy Economics, 31, 838-851. https://doi.org/10.1016/j.eneco.2009.05.016

Amano, R. A., \& Van Norden, S. (1998). Oil prices and the rise and fall of the US real exchange rate. Journal of International Money and Finance, 17, 299-316. https://doi.org/10.1016/S0261-5606(98)00004-7

Atems, B., Kipper, D., \& Lam, E. (2015), Do exchange rates respond asymmetrically to shocks in the crude oil market? Energy Economics, 49, 227-238. https://doi.org/10.1016/j.eneco.2015.01.027 
Backus, D. K., \& Crucini, M. J. (2000). Oil prices and the terms of trade. Journal of International Economics, 50, 185-213. https://doi.org/10.1016/S0022-1996(98)00064-6

Basher, S. A., Hag, A. A., \& Sadoski, P. (2016). The impact of oil shocks on exchange rates: A Markov-switching approach. Energy Economics. https://doi.org/10.1016/j.eneco.2015.12.004

Chen, S. S., \& Chen, H. C. (2007). Oil prices and real exchange rates. Energy Economics, 29, 390-404. https://doi.org/10.1016/j.eneco.2006.08.003

Hamilton, J. D. (1983). Oil and the macro economy since World War II. Journal ofPolitical Economy, 91, 228-248. https://doi.org/10.1086/261140

Huang, Y., \& Guo, F. (2007). The role of oil price shocks on China's real exchange rate. China Economic Review, 18, 403-416. https://doi.org/10.1016/j.chieco.2006.02.003

International Energy Agency. (1995). World Energy Outlook, 1-570.

Kilian, L. (2009). Not all oil price shocks are alike: disentangling demand and supply shocks in the crude oil market. American Economic Review, 99, 1053-1069. https://doi.org/10.1257/aer.99.3.1053

Koenker, R., \& Bassett, G. (1978). Quantile Regression. Econometrica, 46, 33-50. https://doi.org/10.2307/1913643

Law CH. (2018), The heterogeneous impact of oil price on exchange rate: Evidence from Thailand. Economics Bulletin, 38(4), 1748-1756.

Liu, Y., Failler, P., Peng, J., \& Zheng, Y. (2020). Time-Varying Relationship between Crude Oil Price and Exchange Rate in the Context of Structural Breaks. Energies, 13(9), 1-17. https://doi.org/10.3390/en13092395

Lizardo, R., \& Mollick, A. (2010), Oil price fluctuations and the U.S. dollar exchange rates. Energy Economics, 32, 399-408. https://doi.org/10.1016/j.eneco.2009.10.005

Reza-zadeh, A. (2016). The impact of oil shocks on exchange rate in Iran: A Markov-switching approach. Journal of Economic Research and Policies, 24(79), 123-144.

U.S. Energy Information Administration. Short-Term Energy Outlook. Pp. 1-50.

Wang, Y., \& Wu, C. (2012), Energy prices and exchange rates of the U.S. dollar: Further evidence from linear and nonlinear causality analysis. Economic Modeling, 29, 2289-2297. https://doi.org/10.1016/j.econmod.2012.07.005

Zhang, Y.-J., Fan, Y., Tsai, H.-T., \& Wei, Y.-M. (2008). Spillover effect of US dollar exchange rate on oil prices. Journal of Policy Modeling, 30(6), 973-991. https://doi.org/10.1016/j.jpolmod.2008.02.002

\section{Copyrights}

Copyright for this article is retained by the author(s), with first publication rights granted to the journal.

This is an open-access article distributed under the terms and conditions of the Creative Commons Attribution license which permits unrestricted use, distribution, and reproduction in any medium, provided the original work is properly cited. 